\title{
Investigation about the Inhibition of HIV-1 Gp41 Fusion via Andrographis Paniculata: Virtual Screening, Molecular Dynamics Simulation and Free Energy Calculation
}

\author{
Ancy Iruthayaraj and Poomani Kumaradhas*
}

Laboratory of Biocrystallography and Computational Molecular Biology,Department of Physics, Periyar University, Salem-636 011, India

"Corresponding Author

Poomani Kumaradhas

Professor and Head, Department of Physics

Periyar University, Salem-11, Tamilnadu

India

Email:kumaradhas@yahoo.com

Received:13 March 2020; | Revised:03May 2020; | Accepted:23 September 2020

\begin{abstract}
Andrographis Paniculata (AP) is well known for its antiviral and potential AIDS therapeutic property. Based on the experimental evidence we determined to find the potential molecule from AP against HIV-1 viral fusion. Hence the reported compounds present in the AP has been chosen for virtual screening and the results indicate that the molecules Bis-andrographolide ether and Beta-ducosterol forms required intermolecular interactions and have better binding affinity towards NHR of HIV-1 gp41 fusion inhibition. Further molecular docking, MD simulation, free energy calculations and ADME prediction have been carried out. The RMSD, RMSF, DSSP and PCA analysis reveals that mutation and binding mode of the molecules has high impact on the flexibility of gp41. Especially Intermolecular interactions and binding free energy values of these two molecules conveyed that the molecules will affect the viral fusion and six helix bundle formation. The ADME results proved their drug likeness properties. The present study indicates that the molecules can be the promising small molecule inhibitors of HIV-1 viral fusion and further drug designing.
\end{abstract}

Keywords: Andrographis Paniculata, Wild and mutant NHR of gp41, MD simulation, Intermolecular interactions, Binding Free energy calculations

\section{Introduction}

Human Immunodeficiency Virus (HIV) belongs to retroviral family cause Acquired Immune Deficiency Syndrome (AIDS) and leads to death. So far overall 78 million people were infected and 38 million people are currently living with HIV in worldwide ${ }^{[1]}$. Highly Activated Anti Retroviral Therapy (HAART) treatment is currently available for HIV patients increased the time period of AIDS related deaths, but failed to reduce the new infections and eradicate the virus from human being. Overall, availability of the drugs across the world, drug resistant and severe side effects of HAART 
regimen drugs make the HIV infected patients' life more difficult ${ }^{[2-5]}$. While investigating the mode of action of HAART drugs, the fusion inhibitors created an attractive attention among the researchers, because most of the fusion inhibitors under development targets viral glycoprotein 41 (gp41) and not any other cellular proteins which causes minimum side effects. Reports also confirm that the side effects caused by fusion inhibitors are few when compared with the other classes of drugs ${ }^{[6,7]}$. The N-hepted repeat (NHR) of viral envelope glycoprotein 41 (gp41) is the main target for fusion inhibitors that prohibit the binding of $\mathrm{C}$-hepted repeat (CHR) and six helix bundle formation which leads to inactivation of viral fusion with $\mathrm{T} 4$ helper cells ${ }^{[8-10]}$. There are three highly conserved cavities [First cavity (C1) (Val10-Asn15), second cavity (C2) (Leu17-Leu26) and third cavity (C3) (Gln28Arg40)] and GIV motif ${ }^{[11-12]}$ present in the NHR of gp41 and multiple mutations in NHR leads to the inactivation of viral fusion ${ }^{[13]}$. To prevent the viral fusion, enfuvirtide drug was approved by FDA in $2003^{\text {[14] }}$, which mimics the CHR of gp41, and it successfully inhibit the fusion process at nM level. Lipid binding domain (LBD) of Enfuvirtide binds with the $\mathrm{C} 1$ and $\mathrm{C} 2$ cavities of NHR region and inhibits the fusion effectively. However, enfuvirtide has disadvantages, like lagging of pocket binding domain (PBD), development of resistance viral strains, high cost, manufacturing difficulties, lower half life $(\sim 3.6 \mathrm{~h})$ and as a peptide, enfuvirtide undergoes catabolism to its component amino acids [15-17]. These factors urge the researchers to develop potential tight binding fusion inhibitor; especially small molecule inhibitors of HIV-1 fusion. These inhibitors should have several advantageous properties than peptide based fusion inhibitors such as longer half life, low cost and oral bioavailability. Still the efforts for small molecule drug discovery have failed to achieve the potency afforded by peptide based inhibitors which exhibits $\mathrm{nM}$ range of inhibition. Therefore by identifying the small molecules that forms more intermolecular interactions with NHR of gp41 beyond the hydrophobic pocket to form additional interactions we can improve the potency of small molecule inhibitors; because NHR has multiple potential interactive sites both within a single groove and

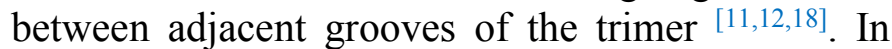
this scenario, the drugs derived from the natural products will cause minimum side effects and also helps to overcome the viral resistance ${ }^{[19]}$. Therefore, identifying the potential drugs derived from natural sources will be the hope for millions of people living with HIV. Accordingly Andrographis Paniculata (kalmegh) plants have been utilized for the treatment of various viral infections for several decades and many other inflammatory disorders $[20,21]$. Reports also proclaimed that the plant has potential AIDS therapeutic property ${ }^{[22]}$. Hence the detailed investigations about the HIV-1 fusion inhibition mechanism of compounds present in the plants are necessary for drug development. Approximately there are 35 compounds extracted from this plants and screening of these compounds against HIV-1 viral enzymes/proteins will progress the researchers to find out the potential drug with minimum side effects. Hence identifying small molecule inhibitors from the compounds present in Andrographis Paniculata will lead to find or design the potential drug against wild and mutant HIV-1 gp41 with minimum side effects. In the present study virtual screening of the 35 compounds present in the plant has been carried out. Further to find the mechanism of action and binding nature of the top two high scored molecules (scheme 1) molecular docking, molecular dynamics (MD) simulation, binding free energy and ADME prediction values were calculated with wild and mutant NHR of gp41. 


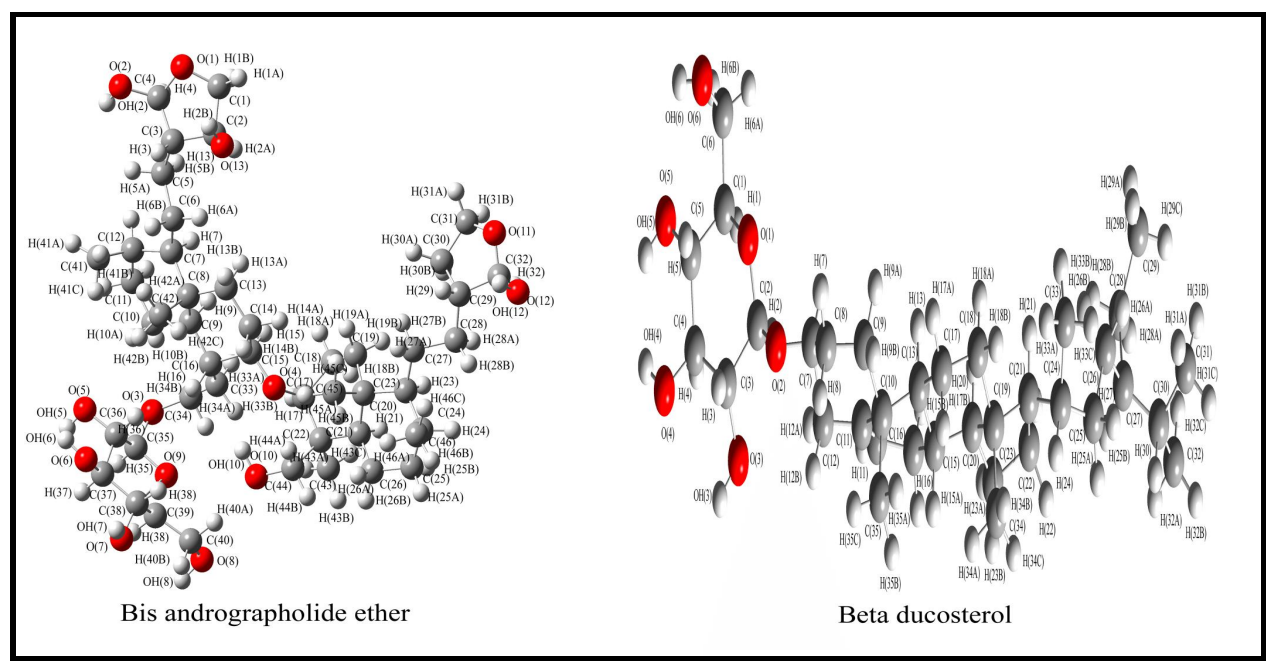

Scheme 1: Chemical structure of the molecules Bis-andrographolide ether and Beta ducosterol

\section{Computational Details}

\subsection{Screening and Molecular docking studies}

The molecular screening is a computer based tool to identify the novel compounds that able to bind with protein molecule. To identify a potential natural compound to inhibit the HIV-1 gp41 fusion, we have chosen a set of 35 natural compounds from the plant Andrographis Paniculata; obtained from PUBCHEM and CHEMSPIDER databases. All these molecules were screened for NHR of gp41 using DOCK $6^{[23]}$. There are many crystal structures are available for gp41 domain; among these, crystal structure of HIV-1 gp41 which belongs to subtype D was chosen (PDB id: 3UIA), which has more rapid rate of disease progression and higher mortality rate than other subtypes ${ }^{[24]}$. The binding energy of 35 compounds obtained from screening process are listed in Table S1. From that screening process, Bis-andrographolide ether [-34.9 $\mathrm{kcal} / \mathrm{mol}]$ and Beta-ducosterol [-30.2 $\mathrm{kcal} / \mathrm{mol}]$ molecules gave highest grid-score values (Table S1). Initially, the geometry of these three molecules were optimized with B3LYP/6-311G** level of density functional theory (DFT) ${ }^{[25-26]}$ using Gaussian03 software [27]. The G8D/V10A/Q12H/N15D mutations were selected based on enfuvirtide resistance ${ }^{[28]}$ and these mutations were applied on 3UIA pdb structure using PyMOl software ${ }^{[29]}$. Further the docking analysis of these three optimized molecules with wild and mutant NHR of gp41 has been performed using DOCK 6 software ${ }^{[23]}$. The intermolecular interactions between the inhibitors and NHR of gp41 were analyzed by PyMol and Discovery studio visualizer $^{[30]}$.

\subsection{Molecular Dynamics Simulations}

To understand the stability and the intermolecular interactions of these two molecules in the active site of wild and mutant NHR of gp41, MD simulations of Bis-andrographolide ether-gp41 and Beta-ducosterol-gp41 complexes were carried out using Sander routine of AMBERTOOLS14 package ${ }^{[31]}$. The parameter and coordinate files of the complex were prepared using $A M B E R$ ff $14 S B$ force field and leap module ${ }^{[32]}$. The orthorhombic shell of TIP3P water box were generated with a minimum solute-wall at $8 \AA$ distance and $3 \mathrm{Cl}$ - ions were added, to neutralize the charges ${ }^{[33-34]}$ of the complex system. All the structures were minimized to remove steric clashes and annealed from 0 to 300 $\mathrm{K}$ for $200 \mathrm{ps}$ time period with the maintenance of canonical ensemble (NVT) ${ }^{[35]}$. The molecular dynamics production phase was initiated and continued to $50 \mathrm{~ns}$ in 2 fs time step at constant temperature $(300 \mathrm{~K})$ and pressure $(1$ bar $)$ using the same Langevin thermostat and Berendsen barostat as in the heating process ${ }^{[36-37]}$. The SHAKE algorithm was used to constrain the bonds of nonpolar hydrogen atoms ${ }^{[38]}$. VMD ${ }^{[39]}$ and CPPTRAJ ${ }^{[40]}$ software were used to analyze the MD trajectory. CPPTRAJ software is also used to study Defined Secondary Structure of Proteins (DSSP). The molecules Bis-andrographolide ether and Betaducosterol were lifted up from wild and mutant gp41 complexes during 50ns MD simulation and single point energy calculation has been carried out 
with B3LYP/6-311G** level of density functional theory (DFT) ${ }^{[25-26]}$ using Gaussian03 software ${ }^{[27]}$ to understand the conformational modifications of these molecules from wild to mutant type gp41.

\subsubsection{Principal Component Analysis (PCA)}

Principle component analysis (PCA) in Cartesian space can be used to assess the dynamic properties (i.e. the motions) of a given system. The following steps are involved in PCA analysis. (i) Each frame of the trajectory is RMS-fit to the overall average coordinates in order to remove the translational and rotational movements from the last 1000 frames of MD trajectories and the covariance matrix was created. (ii) The covariance matrix was diagonalized to produce set of eigenvectors and eigenvalues. These eigenvalues are represented by concerted motions of the wild and mutant Bisandrographolide ether-gp41, and Beta-ducosterolgp41 complexes along every direction which is obtained from amplitude of eigenvectors and the displacement of atoms along each eigenvector ${ }^{[41-42]}$. The most prominent motions of a protein molecule were given by the eigenvectors related with the first two modes of the covariance matrix. PCA was carried out for the backbone $\mathrm{C}$ a atoms extracted from the last 1000 snapshots of the MD trajectories using CPPTRAJ ${ }^{[40]}$ and the scatter plots were generated for the first two principal components of wild and mutated complexes using xmgrace.

\subsection{Free Energy calculations}

MM-PBSA, MM-GBSA and decomposition free energy also calculated from the MD trajectories of wild and mutant Bis-andrographolide ether-gp41 and Beta-ducosterol-gp41 and complexes using AMBERTOOLS14 package [31]. GBSA calculation was carried out based on GB model developed by A. Onufriev, D. Bashford and D.A. Case ${ }^{[43]}$ and the PBSA calculation was initiated with atomic radii present in the prmtop file. The salt concentration of mobile counter ions in solution was set to $0.1 \mathrm{M}$ and the ionic strength value was set to $0.1 \mathrm{mM}$. Hence, 5000 frames were processed for overall MM-PBSA, MM-GBSA and decomposition free energy calculations. The change in free energy was calculated by using,

$$
\Delta \mathrm{G}=<\mathrm{G}_{\text {complex }}>-<\mathrm{G}_{\text {receptor }}>-<\mathrm{G}_{\text {ligand }}>
$$

Where, $<\mathrm{G}>$ indicates an ensemble average over the values calculated by post processing a series of frames from molecular dynamics trajectories, the binding energy of wild and mutant Bis-andrographolide ether-gp41 and Betaducosterol-gp41 solvated complex systems are given by,

$$
\Delta \mathrm{G}_{\mathrm{aq}}=\Delta \mathrm{G}_{\mathrm{gas}}+\Delta \mathrm{G}_{\mathrm{sol}}
$$

The MM-PBSA and MM-GBSA calculations [44-49] involves the computation of absolute binding free energy values by calculating average free energies of the wild and mutant Bisandrographolide ether-gp41 and Beta-ducosterolgp41 complexes, the wild and mutant gp41 alone and Bis-andrographolide ether and Beta-ducosterol alone. Energy decomposition analysis is a valuable analytical tool that partitions the intermolecular interaction energy into energy components such as internal energy, van der Waals energy, electrostatic energy, polar and non-polar salvation energy contributions and related chemical phenomena ${ }^{[50]}$. Hence, energy decomposition values for Bisandrographolide ether and Beta-ducosterol with wild and mutant gp41 were calculated using AMBERTOOLS14 package ${ }^{[31]}$.

\subsection{ADME Prediction}

The physicochemical, biological and pharmacokinetics profiles of the Bisandrographolide ether and Beta-ducosterol molecules were predicted from absorption, distribution, metabolism and excretion (ADME) properties using Qikprop v3.0 implemented in Schrodinger software package ${ }^{[51]}$. This is standard as being dissimilar to other $95 \%$ of the known drugs. Predicted significant ADME properties of these molecules are in accordance with Lipinski' $\mathrm{s}$ rule of five and by utilizing the physicochemical properties of the molecules QikProp also evaluate the oral bioavailability.

\section{Results and Discussion}

\subsection{Evaluation of MD simulation}

Figure (1) shows the (a) RMSF, (b) PCA and (c)DSSP plots of wild and mutant BisAndrographolide ether-gp41 and Beta-ducosterolgp41 complexes. The RMSD and Rg plots of both wild and mutant complexes were plotted and shown 
in Figure $\mathrm{S} 1(\mathrm{a} \& \mathrm{~b})$. The RMSD value of backbone $\mathrm{C} \alpha$ atoms and the RMSF values of amino acids present in wild and mutant complexes indicate the stability of the complexes over 50 ns simulation. The high Rg values of both complexes (Figure S1b) indicate the $\alpha$-helical nature and degree of compactness of the complex system ${ }^{[52]}$.

The RMSF values of active site amino acids of wild and mutant Bis-andrographolide ether-gp41 complex was low this may be due to the binding of this ligand molecule in that region and alter the

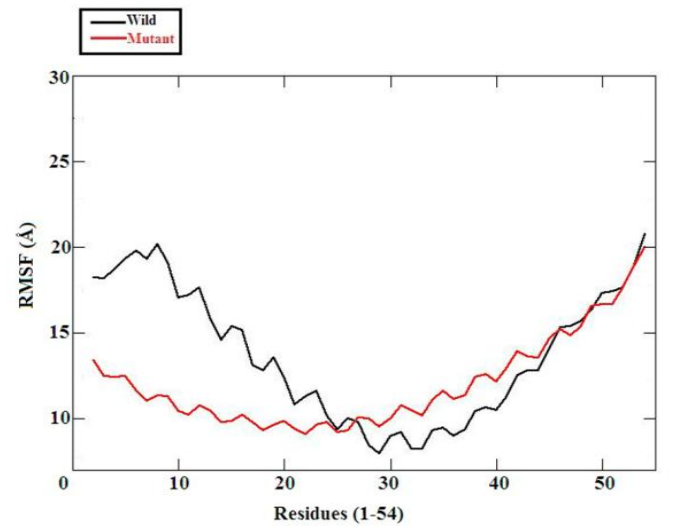

Bis-Andrographolide ether flexibility of the complex structures. The RMSF values of wild type Beta-ducosterol-gp41 complex gets started to decrease from the first amino acid and remains low (figure 1a) and the RMSF value of mutant complex begins to increase from the amino acid Thr30; this indicates that Beta-ducosterol binds with the third (wild) and second (mutant) cavity of NHR of gp41 and affects the flexibility of those regions.

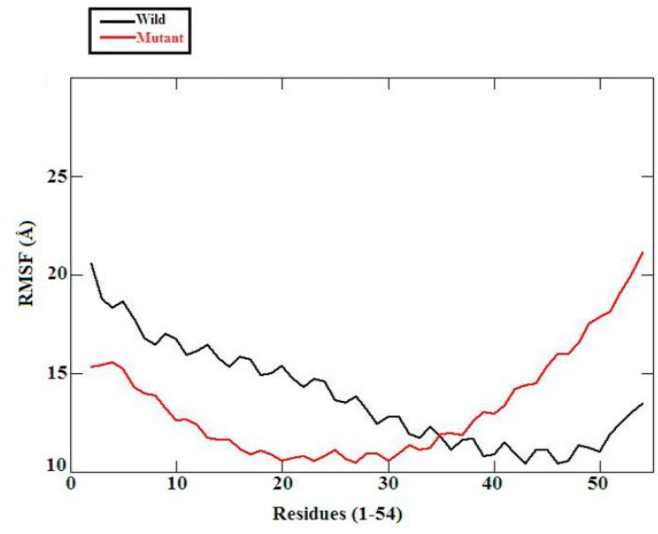

Beta-ducosterol

Figure 1(a): RMSF plot of wild and mutant Bis-Andrographolide ether-gp41 and Beta-ducosterol-gp41 complexes

The principal component with the large eigen values contributes to the higher motion of the protein ${ }^{[53]}$. Hence mutant type complexes of two

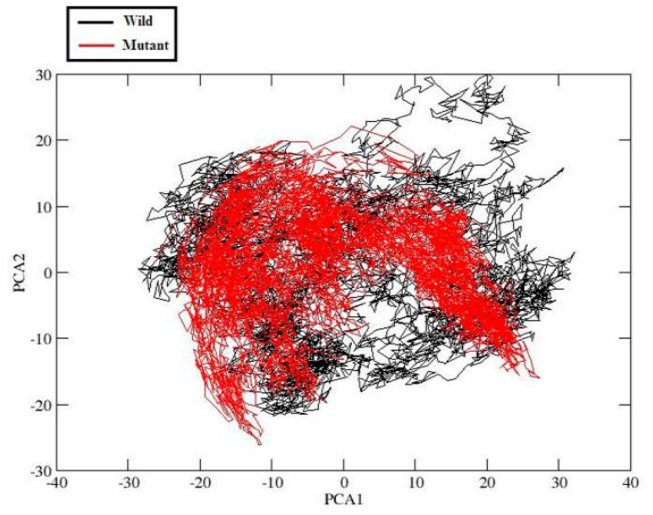

Bis-Andrographolide ether molecules exhibit small motion than their wild type complexes which indicates that the flexibility of the protein was decreased due to the effect of mutation.

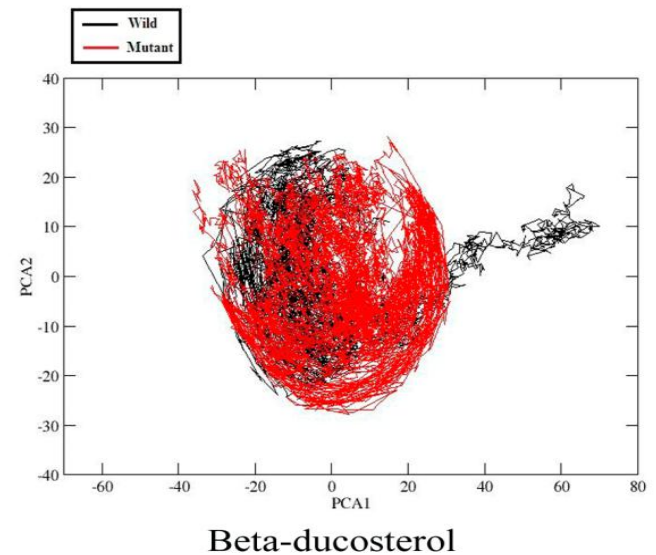

Figure 1(b): PCA plot of wild and mutant Bis-Andrographolide ether-gp41 and Beta-ducosterol-gp41 complexes

DSSP map reveals the $\alpha$-helix conformation of the complex structure. Overall, wild type complex exhibits high conformational modifications than the mutant complex, this indicates that the high flexibility of the wild type complex.
The RMSF, Rg, PCA and DSSP results are well correlated and witnessed that both binding of ligand and the influence of mutation affects the conformation of the complex structure. 


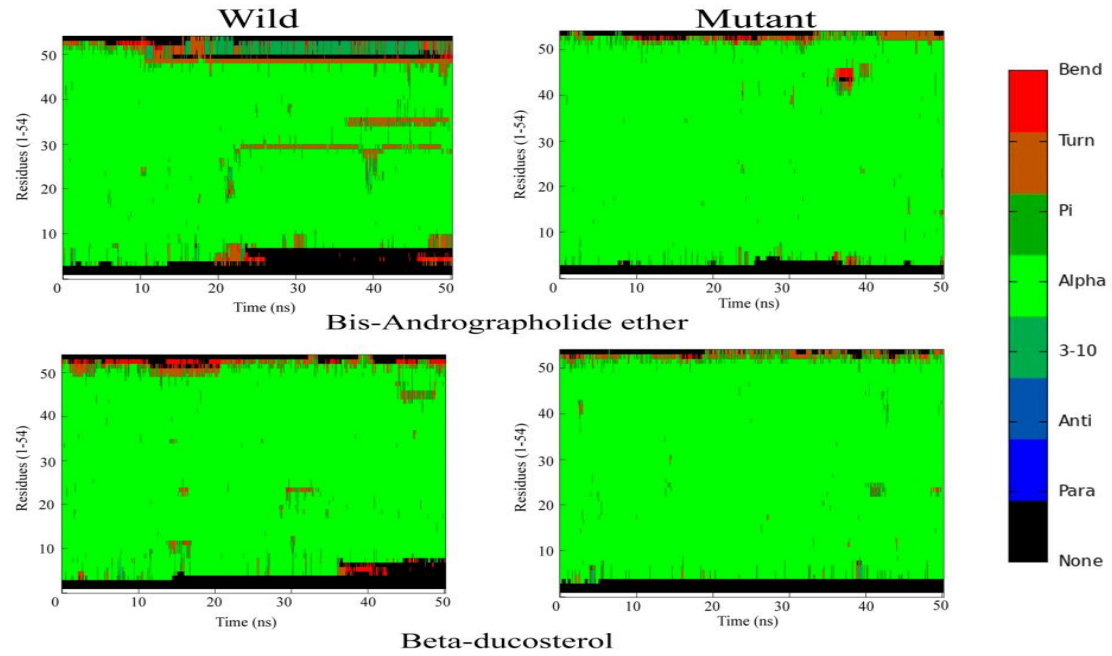

Figure 1(c): DSSP map of wild and mutant Bis-Andrographolide ether-gp41 and Beta-ducosterol-gp41 complexes

\subsection{Binding free energy calculations}

The MM-GBSA/PBSA binding free energy and per residue decomposition free energy values of Bis-andrographolide ether-gp41 and Betaducosterol-gp41 complexes are listed in Table S2. To predict the bio-molecular behavior depends on the concepts, where the solvent is taken into account through its average effects and the results are comparable with the experimental methods. One of the most popular solvent models is based on the MM-PBSA/GBSA equations and the results are more accurate than the molecular docking analysis [48, 54]. The MM-PBSA binding free energy values of the two complexes, wild and mutant are $-30.9 /-22.4$ and $-28.5 /-27.9 \mathrm{kcal} / \mathrm{mol}$ respectively. Per residue decomposition free energy values of wild and mutant Bis-andrographolide ether-gp41 and Betaducosterol-gp41 complexes were calculated and the values are plotted in Figure 2.

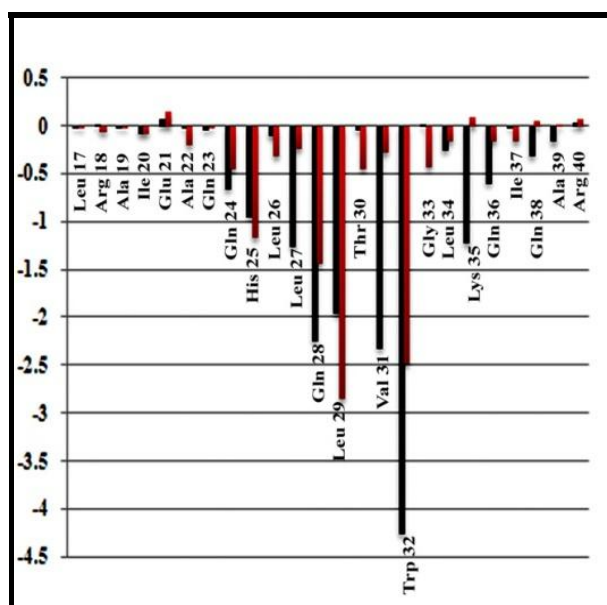

(a)

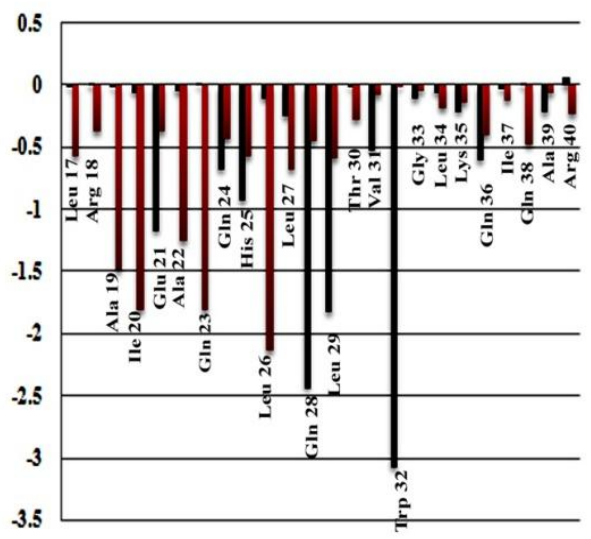

(b)

Figure 2: Per residue decomposition free energy plots of (a) Bis-andrographolide ether-gp41 and (b) Betaducosterol-gp41 complexes

In both wild and mutant complexes, the amino acids His25, Leu27, Gln28, Leu29, Val31, Trp32, Lys35, Gln36 and Gln38 are important for viral fusion ${ }^{[55-56]}$ and contributed lesser energy for the binding of Bis-andrographolide ether molecule.
The third cavity amino acids of wild type NHR of gp41, Gln28, Leu29 and Trp32 spent lower energy for the Beta-ducosterol binding.

In mutant type, the amino acids belongs to the second cavity of gp41 contributes lesser energy for 
the Beta-ducosterol binding ${ }^{[8-9]}$ that contains the amino acid Arg18, which is the important amino acid for gp41 fusion and the interaction of ligand with this amino acid leads to the inhibition of viral fusion ${ }^{[57,58]}$.

\subsection{Structural aspects}

\subsubsection{Conformation analysis}

The molecules Bis-andrographolide ether and Beta-ducosterol exhibit different conformation in wild and mutant type of gp41 and subjected to rapid changes during MD simulation, this indicates the effect of mutation on its binding mode. During the MD simulation, the molecular shift and conformational modification of the molecules occurs in the active site of gp41 and it is shown in Figure 3. The torsion angle values of the molecules Bis-andrographolide ether and Beta-ducosterol present in the wild and mutant gp41 complexes during 50 ns MD simulation are listed in Table 1.

The molecule Bis-andrographolide ether molecule forms stable intermolecular interactions with the third cavity of wild and mutant NHR of gp41. The atom H(29) forms hydrogen bonding interactions with the amino acids Gln24 (wild) and His25 (mutant) hence the corresponding bonds $\mathrm{H}(29)-\mathrm{C}(29)-\mathrm{C}(28)-\mathrm{H}(28 \mathrm{~A})$ and $\mathrm{H}(29)-\mathrm{C}(29)-$ $\mathrm{C}(28)-\mathrm{H}(28 \mathrm{~B})$ undergoes gauche to trans $\left(67^{\circ}\right.$ to $\left.174.1^{\circ}\right)$ and trans to gauche $\left(179^{\circ}\right.$ to $\left.67.1^{\circ}\right)$ conformation modification. Also the $\mathrm{O}(1), \mathrm{O}(8)$ and $\mathrm{O}(13)$ atoms of the molecule Bis-andrographolide ether forms intermolecular interactions with the amino acids Ile20 and Val31 of wild type gp41 and this interaction was disappeared in mutant complex. Hence the bonds $\mathrm{OH}(2)-\mathrm{O}(2)-\mathrm{C}(4)-\mathrm{O}(1), \mathrm{OH}(8)-$ $\mathrm{O}(8)-\mathrm{C}(40)-\mathrm{C}(39)$ and $\mathrm{C}(3)-\mathrm{C}(2)-\mathrm{O}(13)-\mathrm{OH}(13)$ undergoes trans to cis $\left(159^{\circ}\right.$ to $\left.25.9^{\circ}\right)$, trans to gauche $\left(164^{\circ}\right.$ to $\left.-57.1^{\circ}\right)$ and gauche to cis $\left(65^{\circ}\right.$ to $\left.8.4^{\circ}\right)$ conformation modification from wild to mutant type. The atoms $\mathrm{H}(43 \mathrm{~B})$ forms Hydrogen bonding interactions with the amino acid Gln 28 of mutant gp41 and the bond $\mathrm{C}(15)-\mathrm{C}(16)-\mathrm{C}(43)-$ $\mathrm{H}(43 \mathrm{~B})$ modified to gauche to trans $\left(-57.7^{\circ}\right.$ to $\left.172.1^{\circ}\right)$ conformation. Overall from wild to mutant type the bond $\mathrm{C}(30)-\mathrm{C}(31)-\mathrm{O}(11)-\mathrm{C}(32)$ of tetrahydrofuran ring undergoes cis to gauche $\left(-4.9^{\circ}\right.$ to $-45.1^{\circ}$ ) conformation (Figure 3 ).

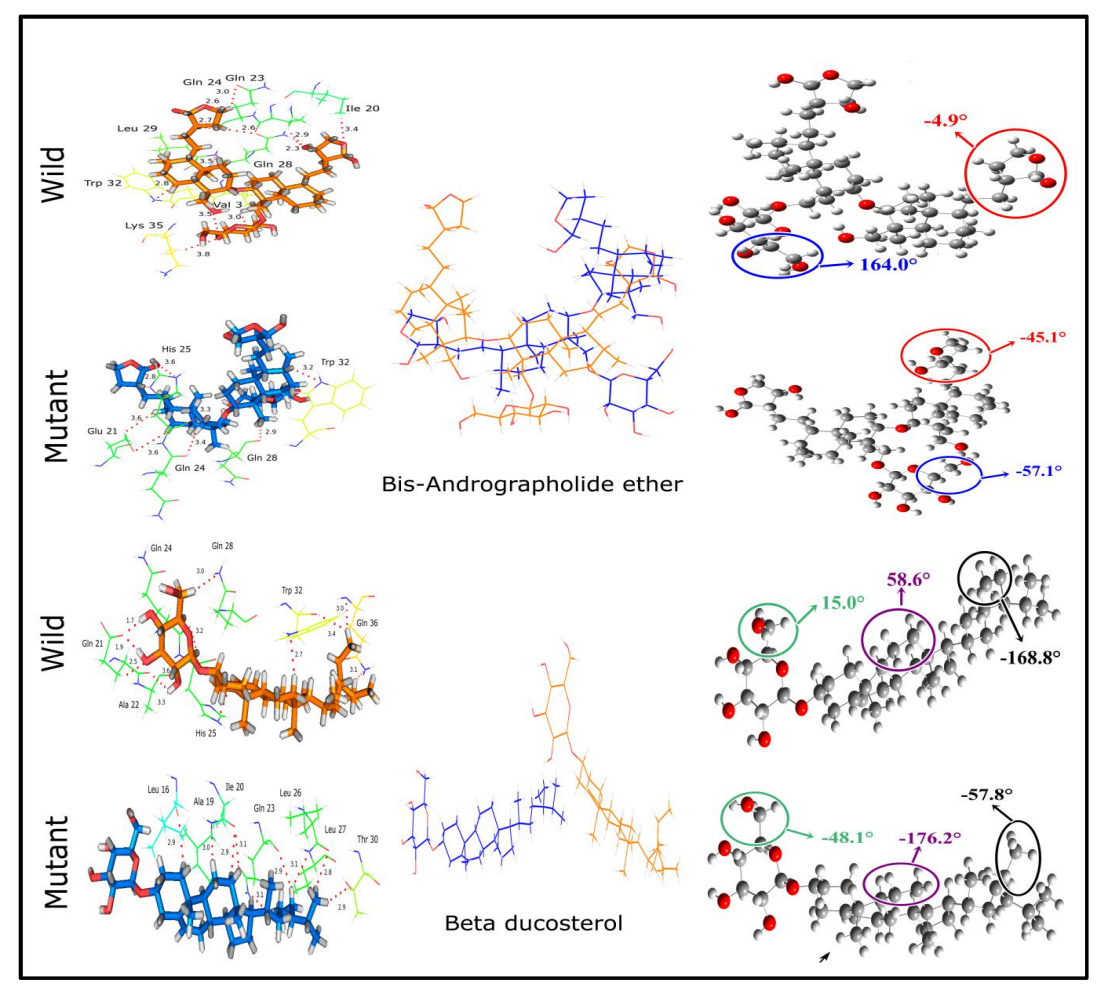

Figure 3: Representation of molecular shift and molecular conformation of the molecules (a) Bisandrographolide ether and (b) Beta ducosterol in the active site of wild and mutant NHR of gp41 during MD simulation [Orange: Wild; Blue: Mutant] 
The molecule beta ducosterol also undergoes many conformational modifications. Especially the atoms $\mathrm{H}(6 \mathrm{~B}), \mathrm{H}(17 \mathrm{~B})$ and $\mathrm{H}(29)$ forms strong Hydrogen bonding interactions with the amino acids Gln28, Trp32 and Gln36 of the wild type gp41, respectively. Hence the bonds $\mathrm{H}(6 \mathrm{~B})-\mathrm{C}(6)-\mathrm{O}(6)-$ $\mathrm{OH}(6), \mathrm{H}(17 \mathrm{~B})-\mathrm{C}(17)-\mathrm{C}(16)-\mathrm{C}(12), \mathrm{H}(29)-\mathrm{C}(29)-$ $\mathrm{C}(30)-\mathrm{H}(30 \mathrm{~A})$ subjected to anticlinal to gauche $\left(15.0^{\circ}\right.$ to $\left.-48.1^{\circ}\right)$, gauche to trans $\left(58.6^{\circ}\right.$ to $\left.-176.2^{\circ}\right)$, trans to gauche $\left(168.8^{\circ}\right.$ to $\left.-57.8^{\circ}\right)$ conformation modification. The atoms H(16A), H(17A), H(17B),
$\mathrm{H}(28 \mathrm{~A})$, and $\mathrm{H}(29)$ forms strong hydrogen bonding interactions with the amino acids Ile20, Ala19, Leu27 and Gln23 of mutant type gp41. Hence the bonds $\mathrm{H}(12)-\mathrm{C}(12)-\mathrm{C}(16)-\mathrm{H}(16 \mathrm{~A}), \mathrm{H}(27 \mathrm{~A})-\mathrm{C}(27)-$ $\mathrm{C}(28)-\mathrm{H}(28 \mathrm{~A}), \quad \mathrm{H}(17 \mathrm{~A})-\mathrm{C}(17)-\mathrm{C}(16)-\mathrm{C}(12)$, $\mathrm{H}(27 \mathrm{~B})-\mathrm{C}(27)-\mathrm{C}(28)-\mathrm{H}(28 \mathrm{~A})$ and $\mathrm{H}(29)-\mathrm{C}(29)-$ $\mathrm{C}(30)-\mathrm{H}(30 \mathrm{~A})$ tends to gauche to trans $\left(48.2^{\circ}\right.$ to $162.4^{\circ} ; 67.1^{\circ}$ to $\left.163.8^{\circ}\right)$, trans to gauche $\left(176^{\circ}\right.$ to $72.7^{\circ} ; 175^{\circ}$ to $49.7^{\circ} ; 168.8^{\circ}$ to $-57.8^{\circ}$ ) conformational modification from wild to mutant type complex.

Table 1: Torsion angle values $\left(^{\circ}\right)$ of the molecules Bis-andrographolide ether and Beta ducosterol from the wild and mutant complexes during MD simulation

\begin{tabular}{lcc}
\hline Bonds & Wild & Mutant \\
\hline Bis-andrographolide ether & & \\
OH(2)-O(2)-C(4)-O(1) & 159 & 25.9 \\
OH(8)-O(8)-C(40)-C(39) & 164 & -57.1 \\
$\mathrm{C}(3)-\mathrm{C}(2)-\mathrm{O}(13)-\mathrm{OH}(13)$ & -65 & 8.4 \\
$\mathrm{C}(15)-\mathrm{C}(16)-\mathrm{C}(43)-\mathrm{H}(43 \mathrm{~B})$ & -57.7 & -172.1 \\
$\mathrm{H}(29)-\mathrm{C}(29)-\mathrm{C}(28)-\mathrm{H}(28 \mathrm{~A})$ & -67 & -174.1 \\
$\mathrm{H}(29)-\mathrm{C}(29)-\mathrm{C}(28)-\mathrm{H}(28 \mathrm{~B})$ & 179 & 67.1 \\
$\mathrm{C}(30)-\mathrm{C}(31)-\mathrm{O}(11)-\mathrm{C}(32)$ & -4.9 & -45.1 \\
Beta ducosterol & & \\
$\mathrm{H}(6 \mathrm{~B})-\mathrm{C}(6)-\mathrm{O}(6)-\mathrm{OH}(6)$ & 150 & -48.1 \\
$\mathrm{H}(12)-\mathrm{C}(12)-\mathrm{C}(16)-\mathrm{H}(16 \mathrm{~A})$ & 48.2 & 162.4 \\
$\mathrm{H}(17 \mathrm{~A})-\mathrm{C}(17)-\mathrm{C}(16)-\mathrm{C}(12)$ & -176 & 72.7 \\
$\mathrm{H}(17 \mathrm{~B})-\mathrm{C}(17)-\mathrm{C}(16)-\mathrm{C}(12)$ & 58.6 & -176.2 \\
$\mathrm{H}(27 \mathrm{~A})-\mathrm{C}(27)-\mathrm{C}(28)-\mathrm{H}(28 \mathrm{~A})$ & 67.1 & 163.8 \\
$\mathrm{H}(27 \mathrm{~B})-\mathrm{C}(27)-\mathrm{C}(28)-\mathrm{H}(28 \mathrm{~A})$ & -175 & 49.7 \\
$\mathrm{H}(29)-\mathrm{C}(29)-\mathrm{C}(30)-\mathrm{H}(30 \mathrm{~A})$ & 168.8 & -57.8 \\
\hline
\end{tabular}

\subsection{Intermolecular interactions}

\subsubsection{Intermolecular Interactions of wild and mutant Bis-andrographolide ether-gp41 complexes}

The nearest neighboring distance of wild and mutant Bis-andrographolide ether-gp41 complexes are listed in Table 2. Figure S2 shows the intermolecular interactions of wild and mutant Bisandrographolide ether-gp41 complexes during docking and $50 \mathrm{~ns}$ MD simulation. There are some common and important interactions present in wild and mutant complex; especially Gln24, Gln28 and
Trp32 amino acids of wild and mutant gp41 forms strong Hydrogen bonding interactions with Bisandrographolide ether at the distances $2.7,2.8,2.8$ $\AA$ (wild type) and $3.4,2.9,3.2 \AA$ (mutant type) respectively. Trp32 is a key binding residue for small molecule based inhibitors ${ }^{[56]}$ where the Bisandrographolide ether forms strong interaction with Trp32 in both wild and mutant type. Leu29, Val31, Lys 35 and Gln38 are also the critical residues for viral fusion ${ }^{[57]}$ and the molecule forms interaction with these amino acids during MD simulation. 
Table 2: Nearest neighboring contacts of Bis-andrographolide ether-gp41 complexes

\begin{tabular}{|c|c|c|c|c|}
\hline \multirow[t]{3}{*}{ Bis-Andrographolide ether $\cdots$ gp41 } & \multicolumn{4}{|c|}{ Distance $(\AA)$} \\
\hline & \multicolumn{2}{|c|}{ Wild } & \multicolumn{2}{|c|}{ Mutant } \\
\hline & Dock & $50 \mathrm{~ns}$ & Dock & $50 \mathrm{~ns}$ \\
\hline \multicolumn{5}{|l|}{ Hydrogen Bonding Interactions } \\
\hline $\mathrm{O} 1 \cdots \mathrm{HD} 13 / \mathrm{Ile} 20$ & -- & 3.4 & -- & -- \\
\hline H24A $\cdots$ OE1/Glu21 & -- & -- & -- & 3.6 \\
\hline $\mathrm{H} 25 \mathrm{~A} \cdots \mathrm{OE} 2 / \mathrm{Glu} 21$ & -- & -- & -- & 3.6 \\
\hline $\mathrm{H} 31 \mathrm{~A} \cdots \mathrm{OE} 1 / \mathrm{Gln} 23$ & - & 3.0 & -- & -- \\
\hline $\mathrm{O} 11 \cdots \mathrm{HB} 3 / \mathrm{G} \ln 24$ & -- & 2.6 & -- & -- \\
\hline $\mathrm{H} 18 \mathrm{~B} \cdots \mathrm{O} / \mathrm{G} \ln 24$ & -- & 2.7 & -- & 3.4 \\
\hline $\mathrm{OH} 12 \cdots \mathrm{NE} 1 / \mathrm{His} 25$ & 3.5 & -- & -- & 3.6 \\
\hline $\mathrm{H} 18 \mathrm{~A} \cdots \mathrm{O} / \mathrm{His} 25$ & -- & -- & -- & 3.3 \\
\hline $\mathrm{H} 29 \cdots \mathrm{ND} 1 / \mathrm{His} 25$ & -- & -- & -- & 2.8 \\
\hline O7*HD11/Leu26 & -- & -- & 3.0 & -- \\
\hline $\mathrm{H} 30 \mathrm{~A} \cdots \mathrm{OE} 1 / \mathrm{G} \ln 28$ & 2.7 & 2.8 & -- & -- \\
\hline $\mathrm{H} 43 \mathrm{~B} \cdots \mathrm{OE} 1 / \mathrm{G} \ln 28$ & -- & -- & -- & 2.9 \\
\hline $\mathrm{O} 13 \cdots \mathrm{HB} 3 / \mathrm{G} \ln 23 / \mathrm{HE} 22 / \mathrm{G} \ln 28$ & -- & $2.9,2.3$ & -- & -- \\
\hline H45B $\cdots \mathrm{N} /$ Leu29 & -- & 3.5 & -- & -- \\
\hline O10 $\cdots$ HD12/Leu29 & -- & -- & 3.3 & -- \\
\hline O13 $\cdots$ HG21/Thr30 & -- & -- & 2.7 & -- \\
\hline $\mathrm{H} 2 \cdots \mathrm{O} / \mathrm{Thr} 30$ & -- & -- & 3.0 & -- \\
\hline O8 $\cdots$ HG23/Val31 & -- & 3.0 & -- & -- \\
\hline $\mathrm{OH} 8 \cdots \mathrm{O} / \mathrm{Val} 31$ & -- & 3.5 & -- & -- \\
\hline $\mathrm{O} 13 \cdots \mathrm{HO} 6 / \mathrm{Val} 31$ & 3.3 & -- & -- & -- \\
\hline O3*HO1/Trp32 & 3.2 & -- & -- & -- \\
\hline $\mathrm{O} 5, \mathrm{O} 7 \cdots \mathrm{HO} 6 / \mathrm{Trp} 32$ & $2.6,2.7$ & -- & -- & -- \\
\hline $\mathrm{OH}(12) \cdots \operatorname{Trp} 32$ (Pi-Orbitals) & -- & -- & 2.5 & -- \\
\hline $\mathrm{H} 12 \cdots \mathrm{NE} 1 / \operatorname{Trp} 32$ & -- & 2.8 & -- & 3.2 \\
\hline $\mathrm{H} 48, \mathrm{H} 52 \cdots \mathrm{O} / \mathrm{Gly} 33$ & -- & -- & $3.3,3.1$ & -- \\
\hline O11․HA/Leu34 & -- & -- & 2.8 & -- \\
\hline $\mathrm{O} 12 \cdots \mathrm{HO} 3 /$ Lys 35 & 2.0 & -- & -- & - \\
\hline HO4 $\cdots$ NZ/Lys35 & 3.6 & -- & -- & -- \\
\hline O7*HG3/Lys35 & -- & 3.8 & -- & -- \\
\hline $\mathrm{HO} 5 \cdots \mathrm{NE} 2 / \mathrm{G} \ln 36$ & 2.6 & -- & -- & -- \\
\hline $\mathrm{O} 8 \cdots \mathrm{HO} 3 / \mathrm{G} \ln 36$ & 2.3 & -- & -- & -- \\
\hline $\mathrm{O} 12 \cdots$ HG13/Ile37 & -- & -- & 2.7 & -- \\
\hline \multicolumn{5}{|l|}{ Hydrophobic Interactions } \\
\hline 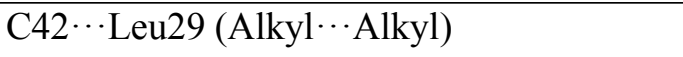 & 4.7 & 4.4 & 4.3 & -- \\
\hline 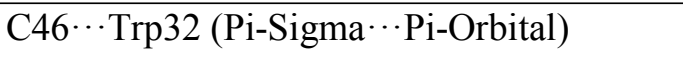 & 3.6 & -- & -- & - \\
\hline 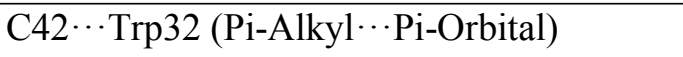 & 4.3 & 3.6 & 5.1 & 4.4 \\
\hline
\end{tabular}

\subsubsection{Intermolecular Interactions of wild and mutant Beta ducosterol-gp41 complexes}

The nearest contact distances of wild and mutant Beta ducosterol-gp41 complexes were listed in table 3. The intermolecular interactions of wild and mutant Beta ducosterol-gp41 complexes during docking and $50 \mathrm{~ns}$ MD simulation are shown in
Figure S3. There are no common interactions present in wild and mutant complex. The amino acids of Gln21, Gln24, His25, Gln28 and Trp32 of wild type gp41 forms strong Hydrogen bonding interactions with Beta ducosterol at the distances 1.7, 3.2, 2.8, 3.0 and $2.7 \AA$ respectively. During MD simulation, the Beta ducosterol forms alkyl $\cdots$ alkyl 
type interaction with Leu29 and alkyl $\cdots$ pi-orbital type interaction with Trp32 which are also the critical residues for viral fusion ${ }^{[54-55]}$. In mutant type Beta ducosterol forms interactions with the amino acids present in the second cavity of gp41.
The amino acids Leu16, Leu17, Ala19, Ile20, Gln23, Leu27 and Thr30 present in the mutant type gp41 forms hydrogen bonding interaction with Beta ducosterol at the distances 2.9, 3.9, 2.9, 3.0, 2.8, 2.9, 3.1 and $2.9 \AA$ respectively (Table 3 ).

Table 3: Nearest neighboring contacts of Beta ducosterol-gp41 complexes

\begin{tabular}{|c|c|c|c|c|}
\hline \multirow[t]{3}{*}{ Beta ducosterol $\cdots$ gp41 } & \multicolumn{4}{|c|}{ Distance $(\AA)$} \\
\hline & \multicolumn{2}{|c|}{ Wild } & \multicolumn{2}{|c|}{ Mutant } \\
\hline & Dock & $50 \mathrm{~ns}$ & Dock & $50 \mathrm{~ns}$ \\
\hline \multicolumn{5}{|l|}{ Hydrogen Bonding Interactions } \\
\hline H18A $\cdots$ O/Leu 16 & -- & -- & -- & 2.9 \\
\hline H17A, H17B $\cdots$ O/Ala19 & -- & -- & -- & $2.9,3.1$ \\
\hline H16A $\cdots$ N/Ile20 & -- & -- & -- & 3.0 \\
\hline 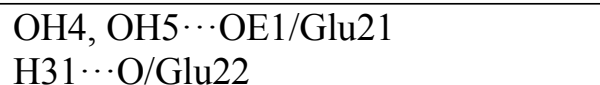 & $\begin{array}{l}-- \\
-\end{array}$ & $\begin{array}{c}1.7,1.9 \\
2.8\end{array}$ & $\begin{array}{l}-- \\
--\end{array}$ & $\begin{array}{l}-- \\
--\end{array}$ \\
\hline $\mathrm{H} 2 \cdots \mathrm{O} / \mathrm{G} \ln 24$ & -- & 3.2 & -- & -- \\
\hline $\mathrm{O} 3 \cdots \mathrm{HA} / \mathrm{HD} 2 / \mathrm{H} / \mathrm{His} 25$ & -- & $2.8,3.2,3.6$ & -- & -- \\
\hline $\begin{array}{l}\mathrm{H} 32 \mathrm{~B} \cdots \mathrm{O} / \text { Lue } 26 \\
\mathrm{H} 28 \mathrm{~A} \cdots \mathrm{N} / \text { Leu } 27 / \mathrm{O} / \mathrm{G} \ln 23 \\
\mathrm{H} 29 \mathrm{~B} \cdots \mathrm{NE} 2 / \mathrm{G} \ln 23\end{array}$ & $\begin{array}{l}-- \\
-- \\
--\end{array}$ & $\begin{array}{l}-- \\
-- \\
--\end{array}$ & $\begin{array}{l}-- \\
-- \\
--\end{array}$ & $\begin{array}{c}2.8 \\
3.1,2.9 \\
3.1\end{array}$ \\
\hline $\begin{array}{l}\mathrm{O} 1, \mathrm{O} 2 \cdots \mathrm{HO} 1 / \mathrm{G} \ln 28 \\
\mathrm{OH} 3 \cdots \mathrm{O} / \mathrm{G} \ln 28 \\
\mathrm{H} 6 \mathrm{~B} \cdots \mathrm{NE} 2 / \mathrm{G} \ln 28\end{array}$ & $\begin{array}{c}2.7,2.8 \\
2.2 \\
--\end{array}$ & $\begin{array}{l}-- \\
-- \\
3.0\end{array}$ & $\begin{array}{l}- \\
-- \\
--\end{array}$ & $\begin{array}{l}-- \\
-- \\
--\end{array}$ \\
\hline H32C $\cdots$ OG1/Thr30 & -- & -- & -- & 2.9 \\
\hline $\begin{array}{l}\mathrm{H} 29 \mathrm{~A} \cdots \mathrm{NE} 2 / \mathrm{Gln} 36 \\
\mathrm{H} 32 \mathrm{~B} \cdots \mathrm{O} / \mathrm{Trp} 32 / \mathrm{N} / \mathrm{Gln} 36 \\
\mathrm{H} 17 \mathrm{~B} \cdots \mathrm{NE} 1 / \operatorname{Trp} 32\end{array}$ & $\begin{array}{l}-- \\
--\end{array}$ & $\begin{array}{c}3.1 \\
3.4,3.0 \\
2.7 \\
\end{array}$ & $\begin{array}{l}-- \\
--\end{array}$ & $\begin{array}{l}-- \\
--\end{array}$ \\
\hline O4*HO1/Lys35 & 2.4 & -- & & \\
\hline O6 $\cdots \mathrm{HE} 22 / \mathrm{G} \ln 36$ & -- & -- & 2.3 & -- \\
\hline $\begin{array}{l}\mathrm{O} 1 \cdots \mathrm{HH} 11 / \operatorname{Arg} 40 \\
\mathrm{O} 2 \cdots \mathrm{HD} 2 / \operatorname{Arg} 40\end{array}$ & $\begin{array}{l}- \\
--\end{array}$ & $\begin{array}{l}- \\
--\end{array}$ & $\begin{array}{l}2.6 \\
2.4\end{array}$ & $\begin{array}{l}-- \\
--\end{array}$ \\
\hline \multicolumn{5}{|l|}{ Hydrophobic Interactions } \\
\hline Lig $\cdots$ Leu16 (Alkyl $\cdots$ Alkyl) & -- & -- & -- & 5.4 \\
\hline 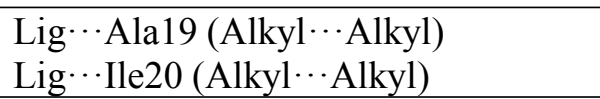 & $\begin{array}{l}-- \\
--\end{array}$ & $\begin{array}{l}-- \\
--\end{array}$ & $\begin{array}{l}-- \\
--\end{array}$ & $\begin{array}{l}5.1 \\
4.8 \\
\end{array}$ \\
\hline C14ㄴ.Leu26 (Alkyl $\cdots$ Alkyl) & -- & -- & 5.3 & 5.2 \\
\hline 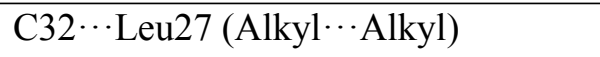 & -- & -- & -- & 4.2 \\
\hline Lig $\cdots$ Leu29 (Alkyl $\cdots$ Alkyl) & 5.3 & 3.4 & 4.3 & -- \\
\hline 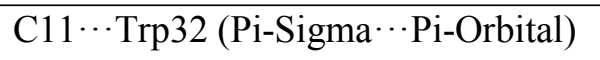 & 3.7 & -- & -- & -- \\
\hline Lig $\cdots$ Trp32 (Pi-Alkyl $\cdots$ Pi-Orbital) & 3.9 & 4.3 & -- & -- \\
\hline
\end{tabular}

\subsection{ADME Prediction}

The ADME results of the chosen molecules in present study are listed in Table 4 and the results were found to be agree with the maximum permissible limits and thus proving their drug likeness properties. The aqueous solubility parameter $(\mathrm{QP} \operatorname{logS})$ of the Bis-andrographolide ether (-4.08) and Beta-ducosterol $(-2.6)$ were also found to be in the permissible range $(<0.5)$. 
Intestinal absorption is one of the important factors to be studied with the absorption of the drug molecules; hence the access of drug molecules to biological membrane was predicted by Caco- 2 cell permeability (QPPCaco) in $\mathrm{nm} / \mathrm{s}$, which is used as model for gut-blood barrier. Caco-2 cell permeability prediction of the molecule Bisandrographolide ether (34.9) indicates good and the molecule Beta-ducosterol (1.7) indicates poor results of good intestinal absorption $[<25$ poor and $>500$ great]. QPlogKhsa descriptor indicating the predicted values of human serum albumin binding and the molecules Bis-andrographolide ether (-0.33) and Beta-ducosterol (-0.95) were found to fall in the permissible range (-1.5 to 1.5$)$. The QPlogHERG denotes IC50 of the blockage of HERG K+ channel blockage. If a compound blocks the potassium channel, it is classified as class III antiarrhythmic agents results in raising of side effects. The activity of the molecules Bisandrographolide ether (-6.2) and Beta-ducosterol (3.5) towards HERG $\mathrm{K}+$ channel was also calculated. From the studies, it was observed that the selected compounds are exhibiting poor values denotes the side effects may not be raised by blocking the HERG K+ channel. Also, the QPlogBB descriptor for blood/brain partition coefficient showed reliable prediction of the molecules Bis-andrographolide ether (-2.9) and Beta-ducosterol (-3.4). The percentage of human oral absorption of the molecules Bis-andrographolide ether $(63.6 \%)$ is high and low for the molecule Beta-ducosterol (16.4\%).

Table 4: ADME properties of Bis-andrographolide ether and Beta-ducosterol molecules

\begin{tabular}{|c|c|c|c|c|c|c|c|c|c|}
\hline Molecules & $\begin{array}{c}\text { MW } \\
\text { (amu } \\
\text { ) }\end{array}$ & $\begin{array}{c}\text { dH } \\
\text { B }\end{array}$ & $\begin{array}{c}\mathbf{a H} \\
\mathbf{B}\end{array}$ & $\begin{array}{c}\text { QPlog } \\
\text { S } \\
\text { mol dm } \\
3\end{array}$ & $\begin{array}{c}\text { QPPCac } \\
\mathbf{n m} / \mathrm{s}\end{array}$ & $\begin{array}{c}\text { QPlogKhs } \\
\mathbf{a}\end{array}$ & $\underset{G}{\text { QPlogHER }}$ & $\underset{\mathrm{B}}{\mathrm{qP} \log \mathrm{B}}$ & $\begin{array}{c}\text { PHO } \\
\text { A } \\
(\%)\end{array}$ \\
\hline $\begin{array}{l}\text { Bis-andrographolide } \\
\text { ether }\end{array}$ & 458.4 & 3 & 10.6 & -4.086 & 34.983 & -0.33 & -6.2 & -2.936 & 63.6 \\
\hline Beta-ducosterol & 354.3 & 6 & 9.7 & -2.625 & 1.659 & -0.93 & -3.5 & -3.42 & 16.4 \\
\hline
\end{tabular}

\section{Conclusion}

Andrographis Paniculata has potential AIDS therapeutic property. Hence virtual screening analysis indicates that the molecules Bisandrographolide ether and Beta-ducosterol forms required intermolecular interactions and better binding affinity towards NHR of gp41. Further molecular docking, MD simulation, free energy calculations and ADME prediction has been carried out for these two molecules to find their stability in the active site of wild and mutant NHR of gp41 and physiological properties. From the RMSD, RMSF, DSSP and PCA analysis we can understand that mutation and binding mode of the molecules highly affects the flexibility of the active site. Especially DSSP map indicates a small $\alpha$-helix to turn conformation modification occurs in all two wild type complexes during MD simulation and no such changes occurred in the mutant complexes which confirm that mutation affects the flexibility of the protein structure. The MM-GBSA/PBSA results specify the affinity of these two molecules towards wild and mutant NHR of gp41 are adequate for fusion inhibition. Per residue decomposition free energy values of both complexes indicates that the molecule Bis-andrographolide ether has lower binding free energy with the third cavity amino acids of wild and mutant gp41 that affirms their better fusion inhibition property. In wild type Beta ducosterol-gp41 complex the amino acids Gln28, Leu29 and Trp32 present in the third cavity spent lower energy for binding. Whereas, in mutant type the second cavity amino acids of gp41 contributes lower energy for Beta ducosterol binding especially with the amino acid Arg18 which is crucial for fusion inhibition. The intermolecular interactions of these two molecules with wild and mutant gp41 conveyed that the molecules will affect the viral fusion and six helix bundle formation. The ADME results of the three molecules were found to be agreeing with the maximum permissible limits and thus proving their drug likeness properties. From the present study we conclude that the molecules 
Bis-andrographolide ether and Beta-ducosterol are the promising small molecule inhibitors of HIV-1 gp41 viral fusion and these molecules can also be used as a template for fusion inhibitor drug designing.

\section{Acknowledgement}

The authors thank C-DAC GARUDA, Bangalore for providing the supercomputing facility.

\section{References}

1 www.who.int/news-room/fact sheets/detail/hivaids (accessed February 27, 2020).a

2 Carr A, Cooper DA. Adverse effects of antiretroviral therapy. Lancet 2000; 356(9239): 1423-1430 DOI: $\quad \underline{10.1016 / S 0140-}$ 6736(00)02854-3

3 Weber J. The pathogenesis of HIV-1 infection. Br Med Bull 2001; 58: 61-72 [PMID: 11714624 DOI: $10.1093 / \mathrm{bmb} / 58.1 .61]$

4 Lewden C, Salmon D, Morlat P, Bevilacqua S, Jougla E, Bonnet F, Heripret L, Costagliola D, May T, Chene G, Mortality study g. Causes of death among human immunodeficiency virus (HIV)-infected adults in the era of potent antiretroviral therapy: emerging role of hepatitis and cancers, persistent role of AIDS. Int J Epidemiol 2005; 34(1): 121-130 [PMID: 15561752 DOI: $10.1093 / \mathrm{ije} / \mathrm{dyh} 307]$

5 Pang W, Tam SC, Zheng YT. Current peptide HIV type-1 fusion inhibitors. Antivir Chem Chemother 2009; 20(1): 1-18 [PMID: 19794228 DOI: 10.3851/IMP1369]

6 Teixeira C, Gomes JR, Gomes P, Maurel F, Barbault F. Viral surface glycoproteins, gp120 and gp41, as potential drug targets against HIV-1: brief overview one quarter of a century past the approval of zidovudine, the first antiretroviral drug. Eur J Med Chem 2011; 46(4): 979-992 DOI: 10.1016/j.ejmech.2011.01.046

7 Craik DJ, Fairlie DP, Liras S, Price D. The future of peptide-based drugs. Chem Biol Drug Des 2013; 81(1): 136-147 [PMID: 23253135 DOI: $10.1111 /$ cbdd.12055]

8 Pasquato A, Dettin M, Basak A, Gambaretto R, Tonin L, Seidah NG, Di Bello C. Heparin enhances the furin cleavage of HIV-1 gp160 peptides. FEBS Lett 2007; 581(30): 58075813 DOI: 10.1016/j.febslet.2007.11.050

9 Eckert DM, Kim PS. Mechanisms of viral membrane fusion and its inhibition. Annu Rev Biochem 2001; 70: 777-810 [PMID: 11395423 DOI: 10.1146/annurev.biochem.70.1.777]

10 Melikyan GB, Markosyan RM, Hemmati H, Delmedico MK, Lambert DM, Cohen FS. Evidence that the transition of HIV-1 gp41 into a six-helix bundle, not the bundle configuration, induces membrane fusion. $\boldsymbol{J}$ Cell Biol 2000; 151(2): 413-423 DOI: 10.1083/jcb.151.2.413

11 Tsvetkov VB, Serbin AV. Molecular dynamics modeling the synthetic and biological polymers interactions pre-studied via docking: anchors modified polyanions interference with the HIV-1 fusion mediator. J Comput Aided Mol Des 2014; 28(6): 647-673 DOI: 10.1007/s10822-014-9749-8

12 Trivedi VD, Cheng SF, Wu CW, Karthikeyan R, Chen CJ, Chang DK. The LLSGIV stretch of the N-terminal region of HIV-1 gp41 is critical for binding to a model peptide, T20. Protein Eng 2003; 16(4): 311-317 [PMID: 12736375 DOI: 10.1093/proeng/gzg036]

13 Eggink D, Bontjer I, Langedijk JP, Berkhout B, Sanders RW. Resistance of human immunodeficiency virus type 1 to a thirdgeneration fusion inhibitor requires multiple mutations in gp41 and is accompanied by a dramatic loss of gp41 function. J Virol 2011; 85(20): 10785-10797 DOI: 10.1128/JVI.05331-11

14 Wild CT, Shugars DC, Greenwell TK, McDanal CB, Matthews TJ. Peptides corresponding to a predictive alpha-helical domain of human immunodeficiency virus type 1 gp41 are potent inhibitors of virus infection. Proc Natl Acad Sci USA 1994; 91(21): 9770-9774 DOI: 10.1073/pnas.91.21.9770

15 Greenberg ML, Cammack N. Resistance to enfuvirtide, the first HIV fusion inhibitor. $\boldsymbol{J}$ Antimicrob Chemother 2004; 54(2): 333-340 [PMID: 15231762 DOI: $10.1093 / \mathrm{jac} / \mathrm{dkh} 330]$

16 Lalezari JP, Henry K, O'Hearn M, Montaner JS, Piliero PJ, Trottier B, Walmsley S, Cohen C, Kuritzkes DR, Eron JJ, Jr., Chung J, DeMasi R, 
Donatacci L, Drobnes C, Delehanty J, Salgo M, Group TS. Enfuvirtide, an HIV-1 fusion inhibitor, for drug-resistant HIV infection in North and South America. N Engl J Med 2003; 348(22): 2175-2185 DOI: 10.1056/NEJMoa035026

17 Eckhardt BJ,Gulick RM, Drugs for HIV Infection, Infectious Diseases (Fourth Edition), 2017, 2(152), 1293-1308.e2.

18 Sofiyev V, Kaur H, Snyder BA, Hogan PA, Ptak RG, Hwang P, Gochin M. Enhanced potency of bivalent small molecule gp41 inhibitors. Bioorg Med Chem 2017; 25(1): 408-420 DOI: 10.1016/i.bmc.2016.11.010

19 Hupfeld J, Efferth T. Review. Drug resistance of human immunodeficiency virus and overcoming it by natural products. In Vivo 2009; 23(1): 1-6 [PMID: 19368117]

20 Pizzorno JE, Murrey MT and Bey HJ HIV/AIDS: Naturopathic Medical Principles and Practice, The Clinician's Handbook of Natural Medicine, 2016, 381-407.

21 Uttekar MM, Das T, Pawar RS, Bhandari B, Menon V, Nutan, Gupta SK, Bhat SV. AntiHIV activity of semisynthetic derivatives of andrographolide and computational study of HIV-1 gp120 protein binding. Eur J Med Chem 2012; 56: 368-374 [PMID: 22858223 DOI: $\underline{10.1016 / \text { j.ejmech.2012.07.030] }}$

22 Calabrese C, Berman SH, Babish JG, Ma X, Shinto L, Dorr M, Wells K, Wenner CA, Standish LJ. A phase I trial of andrographolide in HIV positive patients and normal volunteers. Phytother Res 2000; 14(5): 333-338 DOI: 10.1002/1099-1573(200008)14:5<333::aidptr584>3.0.co;2-d

23 Allen WJ, Balius TE, Mukherjee S, Brozell SR, Moustakas DT, Lang PT, Case DA, Kuntz ID, Rizzo RC. DOCK 6: Impact of new features and current docking performance. J Comput Chem 2015; 36(15): 1132-1156 DOI: $\underline{10.1002 / \text { jcc. } 23905}$

24 Venner CM, Nankya I, Kyeyune F, Demers K, Kwok C, Chen PL, Rwambuya S, Munjoma M, Chipato T, Byamugisha J, Van Der Pol B, Mugyenyi P, Salata RA, Morrison CS, Arts EJ. Infecting HIV-1 Subtype Predicts Disease Progression in Women of Sub-Saharan Africa.
EBioMedicine 2016; 13: 305-314 DOI: 10.1016/j.ebiom.2016.10.014

25 Labanowski JK and Andzelm JW, Density functional methods in chemistry. New York, NY: Springer, 1991

26 Parr RG, Yang W, Density functional theory of atoms and molecules. New York, NY: Oxford, 1989

27 Frisch MJ, Trucks GW, Schlegel HB, Scuseria GE, Robb MA, Cheeseman JR, Pople JA, Wallingford, CT: Gaussian 2004

28 Wensing AM, Calvez V, Gunthard HF, Johnson VA, Paredes R, Pillay D, Shafer RW, Richman DD. 2017 Update of the Drug Resistance Mutations in HIV-1. Top Antivir Med 2016; 24(4): 132-133 PMID: 28208121

29 Delano WL, PyMol molecular graphics system. San Carlos, CA: Delano Scientific 2002

30 Dassault Systems BIOVIA. Discovery studio modeling environment, release. San Diego, $\boldsymbol{C A}$ : 2017

31 Case DA, Babin V,Berryman JT, Betz RM, Cai Q, Cerutti DS, Cheatham TE, Darden TA, Duke RE, Gohlke H, Goetz AW, Gusarov S, Homeyer N, Janowski P, Kaus J, Kolossváry I, Kovalenko A, Lee TS, Le Grand S, Luchko T, Luo R, Madej B, Merz KM, Paesani F, Roe DR, Roitberg A, Sagui C, Salomon-Ferrer R, Seabra G, Simmerling GL, Smith W, Swails J, Walker RC, Wang J, Wolf RM, Wu X and Kollman PA, AMBER. University of California, San Francisco 14, 2014

32 Maier JA, Martinez C, Kasavajhala K, Wickstrom L, Hauser KE, Simmerling C. ff14SB: Improving the Accuracy of Protein Side Chain and Backbone Parameters from ff99SB. J Chem Theory Comput 2015; 11(8): 3696-3713 DOI: $10.1021 /$ acs.jctc.5b00255

33 Harrach MF, Drossel B. Structure and dynamics of TIP3P, TIP4P, and TIP5P water near smooth and atomistic walls of different hydroaffinity. J Chem Phys 2014; 140(17): 174501 DOI: $\underline{10.1063 / 1.4872239}$

34 Pekka $\mathrm{M}$ and Lennart $\mathrm{N}$, Structure and dynamics of the TIP3P, SPC and SPC/E water models at 298 K. J Phys Chem A.2001;105:9954-9960.

DOI: $10.1021 / \mathrm{jp} 003020 \mathrm{w}$ 
35 Glenn JM,Adam $\mathrm{H}$ and Tuckerman ME, Molecular dynamics algorithms for path integrals at constant pressure. $\boldsymbol{J}$ Chem Phys. 1999;110:3275-3290.

DOI: $10.1063 / 1.478193$

36 Jones A, Leimkuhler B. Adaptive stochastic methods for sampling driven molecular systems. J Chem Phys 2011; 135(8): 084125 [PMID: 21895177 DOI: 10.1063/1.3626941]

37 Berendsen HJC, Postma JPM, van Gunsteren WF, Di Nola A and Haak JR. Molecular dynamics with coupling to an external bath. $\boldsymbol{J}$ Chem Phys. 1984;81:3684-3690. DOI:10.1063/1.448118

38 Jean-paul R, Giovanni C, and Berendsen HJC. Numerical integration of the Cartesian equations of motion of a system with constraints: molecular dynamics of n-alkanes. J Comput Phys. 1997;23:327-341. DOI:10.1016/0021-9991(77)90098-5

39 Humphrey W, Dalke A, Schulten K. VMD: visual molecular dynamics. J Mol Graph 1996; 14(1): 33-38, 27-38 [PMID: 8744570 DOI: 10.1016/0263-7855(96)00018-5]

40 Roe DR, Cheatham TE, 3rd. PTRAJ and CPPTRAJ: Software for Processing and Analysis of Molecular Dynamics Trajectory Data. J Chem Theory Comput 2013; 9(7): 3084-3095 DOI: 10.1021/ct400341p

41 Shukla H, Shukla R, Sonkar A, Tripathi T. Alterations in conformational topology and interaction dynamics caused by L418A mutation leads to activity loss of Mycobacterium tuberculosis isocitrate lyase. Biochem Biophys Res Commun 2017; 490(2): 276-282 DOI: $10.1016 /$ j.bbrc.2017.06.036

42 Galindo-Murillo R, Roe DR, Cheatham TE, 3rd. Convergence and reproducibility in molecular dynamics simulations of the DNA duplex d(GCACGAACGAACGAACGC). Biochim Biophys Acta 2015; 1850(5): 10411058 DOI: $10.1016 /$ j.bbagen.2014.09.007

43 Onufriev A,Bashford D and Case DA. Modification of the generalized Born model suitable for macromolecules. J Phys Chem B. 2000;104:3712-3720.

DOI:10.1021/jp994072s

44 Genheden S, Ryde U. The MM/PBSA and MM/GBSA methods to estimate ligand- binding affinities. Expert Opin Drug Discov 2015; 10(5): 449-461 DOI: $\underline{10.1517 / 17460441.2015 .1032936}$

45 Gohlke H, Case DA. Converging free energy estimates: MM-PB(GB)SA studies on the protein-protein complex Ras-Raf. J Comput Chem 2004; 25(2): 238-250 [PMID: 14648622 DOI: $10.1002 /$ jcc.10379]

46 Srinivasan J,Cheatham TE,Cieplak P, Kollman PA and Case DA. Continuum solvent studies of the stability of DNA, RNA, and phosphoramidate-DNA helices. $\boldsymbol{J}$ Am Chem Soc. 1998;120(37):9401-9409.

DOI:10.1021/ja981844

47 Sun H, Li Y, Tian S, Xu L, Hou T. Assessing the performance of $\mathrm{MM} / \mathrm{PBSA}$ and MM/GBSA methods. 4. Accuracies of MM/PBSA and MM/GBSA methodologies evaluated by various simulation protocols using PDBbind data set. Phys Chem Chem Phys 2014; 16(31): 16719-16729 [PMID: 24999761 DOI: $10.1039 / \mathrm{c} 4 \mathrm{cp} 01388 \mathrm{c}]$

48 Hou T, Wang J, Li Y, Wang W. Assessing the performance of the molecular mechanics/Poisson Boltzmann surface area and molecular mechanics/generalized Born surface area methods. II. The accuracy of ranking poses generated from docking. J Comput Chem 2011; 32(5): 866-877 DOI: $10.1002 /$ jcc. 21666

49 Xu L, Sun H, Li Y, Wang J, Hou T. Assessing the performance of MM/PBSA and MM/GBSA methods. 3. The impact of force fields and ligand charge models. $\boldsymbol{J}$ Phys Chem B 2013; 117(28): 8408-8421 [PMID: 23789789 DOI: $10.1021 /$ jp404160y]

50 Phipps MJ, Fox T, Tautermann CS, Skylaris CK. Energy decomposition analysis approaches and their evaluation on prototypical protein-drug interaction patterns. Chem Soc Rev 2015; 44(10): 3177-3211 [PMID: 25811943 DOI: 10.1039/c4cs00375f]

51 Induced Fit docking protocol, (2014). Smallmolecular Drug Discovery suite, Schrödinger 2014-2, version

52 Lobanov M, Bogatyreva NS, Galzitskaia OV. [Radius of gyration is indicator of compactness of protein structure]. Mol Biol (Mosk) 2008; 42(4): 701-706 [PMID: 18856071] 
53 Tai K, Shen T, Henchman RH, Bourne Y, Marchot P, McCammon JA. Mechanism of acetylcholinesterase inhibition by fasciculin: a 5-ns molecular dynamics simulation. $\mathbf{J}$ Am Chem Soc 2002; 124(21): 6153-6161 [PMID: 12022850 DOI: $10.1021 / \mathrm{ja} 017310 \mathrm{~h}]$

54 Rastelli G, Del Rio A, Degliesposti G, Sgobba $M$. Fast and accurate predictions of binding free energies using MM-PBSA and MMGBSA. J Comput Chem 2010; 31(4): 797-810 [PMID: 19569205 DOI: 10.1002/jcc.21372]

55 Maerz AL, Drummer HE, Wilson KA, Poumbourios P. Functional analysis of the disulfide-bonded loop/chain reversal region of human immunodeficiency virus type 1 gp41 reveals a critical role in gp120-gp41 association. J Virol 2001; 75(14): 6635-6644 DOI: $\underline{10.1128 / J V I .75 .14 .6635-6644.2001 ~}$

56 Debnath AK, Radigan L, Jiang S. Structurebased identification of small molecule antiviral compounds targeted to the gp41 core structure of the human immunodeficiency virus type $1 . \boldsymbol{J}$ Med Chem 1999; 42(17): 3203-3209 [PMID: 10464007 DOI: $10.1021 / \mathrm{jm} 990154 \mathrm{t}]$
57 Wang X, Xiong W, Ma X, Wei M, Chen Y, Lu L, Debnath AK, Jiang S, Pan C. The conserved residue Arg46 in the N-terminal heptad repeat domain of HIV-1 gp41 is critical for viral fusion and entry. PLoS One 2012; 7(9): e44874 DOI: 10.1371/journal.pone.0044874

58 Ancy I,Sivanandam M, Kalaivani $\mathrm{R}$ and Kumaradhas P. Insights of inhibition mechanism of sifuvirtide and MT-sifuvirtide against wild and mutant HIV-1 envelope glycoprotein41: a molecular dynamics simulation and binding free energy study, $\mathbf{M o l}$. Simul, (2020) 46:6, 429 439, DOI: $10.1080 / 08927022.2020 .1716978$ 